Zamroni

\title{
DEPRESI PADA WARGA BINAAN PEMASYARAKATAN (WBP) KASUS PEMBUNUHAN DI LEMBAGA PEMASYARAKATAN $X$
}

\author{
Zamroni \\ Fakultas Psikologi Universitas Islam Sultan Agung Semarang, Jl. Kaligawe Raya km 4, Semarang \\ E-mail : zamroni@unissula.ac.id
}

\begin{abstract}
Abstrak
Warga Binaan Pemasyarakatan (WBP) kasus pembunuhan di Lembaga Pemasyarakatan (Lapas) X secara keseluruhan mengalami permasalahan kesehatan mental terutama depresi. Penelitian ini bertujuan untuk mendeskripsikan tingkat depresi serta efek pemenjaraan WBP kasus pembunuhan LAPAS X. Sebanyak 6 orang Warga Binaan Pemasyarakatan kasus pembunuhan menjadi subjek penelitian. Partisipan mengisi Beck Depression Inventory II (BDIII) yang mengukur tingkat depresi yang dialami oleh individu. Hasil penelitian menunjukkan bahwa jika berdasarkan usia, maka WBP usia 18 tahun (16.7\%) usia 23 - 28 tahun (83.3\%), Pendidikan SMP (33.3\%), Pendidikan SMA (33.3\%), Pendidikan SMK (33.3\%), Motif dendam (83.3\%), melumpuhkan (16.7\%). Survey tingkat depresi menunjukkan bahwa semua WPB yang menjadi subjek dalam penelitian mengalami depresi berat (100\%). Hal tersebut disebabkan karena faktor dari dalam diri subjek (internal Factor) seperti merasa diabaikan oleh keluarga, merasa tidak dihargai oleh sesama WBP, merasa khawatir sedangkan faktor dari luar disebabkan karena tuntutan hukuman yang terlalu lama, situasi yang ada di Lapas, keluarga tidak peduli.

Kata kunci: Warga Binaan Pemasayarakatan; Depresi; Kasus Pembunuhan
\end{abstract}

\section{DEPRESSION AMONG MURDER CONVICTED CRIMINALS IN PENITENTIARY X}

\begin{abstract}
The inmates (WBP) with murder cases in Penitentiary (Lapas $X$ ) as a whole experience mental health problems, especially depression. This study aims to describe the level of depression and the effects of imprisonment of WBP in the LAPAS X murder case. A total of 6 prisoners of prison correctional cases were the subject of the study. Participants filled in the Beck Depression Inventory II (BDI-II) which measures the level of depression experienced by individuals. The results showed that if based on age, WBP aged 18 years (16.7\%) aged 23-28 years (83.3\%), junior high school education (33.3\%), high school education (33.3\%), vocational education (33.3\%), revenge motives (83.3\%), paralyzing (16.7\%). Depression level survey shows that all WPB who were subject in the study experienced severe depression (100\%). This is due to internal factors such as feeling neglected by the family, feeling unappreciated by fellow WBP, feeling worried while outside factors are caused by demands for too long a sentence, the situation in prison, the family does not care.

Key words: convicted criminal; penitentiary; depression; murder case
\end{abstract}




\section{Pendahuluan}

Lembaga Pemasyarakatan (lapas) merupakan suatu institusi atau lembaga yang bertujuan untuk memberikan pembinaan bagi seseorang yang melakukan tindak kejahatan yang telah mendapatkan putusan hukum dari pengadilan. Kerangka pembinaan yangdilakukan oleh Lapas ialah pembinaan yang bersifat rehabilitatif serta restoratif (Kaloeti, Rahmandani, Salma, La Kahija, Sakti, 2017). Merujuk pada Undang-Undang Nomor 12 Tahun 1995 pasal 1 yang berlaku di Negara Indonesia, bahwa seseorang yang menjalani hukuman pidana (terpidana) akan mempunyai dampak yang signifikan terhadap diri terpidana seperti kehilangan hak kemerdekaannya. Kondisi Kehilangan kemerdekaan bagi seseorang dapat menurunkan harkat dan martabat seseorang serta harga diri dan hal tersebut akan menjadi stresor yang berat pada individu tertentu.

Mendapat sebutan Narapidana atau Warga Binaan Pemasyarakatan (WBP) di Lapas tentu tidak mudah dihadapi oleh sebagian individu. Hal tersebut berdampak pada konsep diri serta kepercayaan diri bagi WBP. Sebagai penghuni Lapas WBP diharapkan menjadi pribadi yang jauh lebih baik dibanding sebelum mereka masuk menjadi warga binaan Lapas. Namun demikian, proses penyesuain yang dilakukan oleh WBP bukan perkara mudah. Banyak WBP yang terpapar budaya baru yang berbeda sama sekali dengan budaya atau kebiasaan yang dimiliki oleh WBP sebelum masuk menjadi warga binaan Lapas. Kondisi yang demikian tentu menimbulkan efek psikologis negatif bagi WBP yaitu menarik diri, cemas, depresi, mempunyai pemikiran untuk bunuh diri, peningkatan perilaku agresi (Ahmad \& Mazlan, 2014; Tomar, 2013). Hal lain yang menjadi sumber masalah adalah kapasitas Lapas yang tidak memadai, minimnya sarana kesehatan, infrastruktur yang tidak mendukung sehingga hal tersebut dapat memicu timbulnya masalah-masalah psikologis bagi WBP.

Beberapa studi telah dilakukan diantaranya ialah Gussack, (2009) di Florida Amerika Serikat, studi tersebut dilakukan pada kurun waktu 7 tahun (2003 -2009), didapatkan kesimpulan bahwa masalah utama yang dialami oleh lembaga pemasyarakatan adalah depresi sebanyak 25\% WBP diindikasikan mengalami depresi berat, sedangkan 30\% diindikasikan mengalami depresi ringan sampai sedang. Sedangkan Lembaga Kesehatan Dunia (WHO) juga telah mengadakan survey di 12 negara yang mencakup 22.790 narapidana dan menemukan pada tiap bulan terjadi prevalensi psikosis pada Warga Binaan Pemasayarakatan pria 3,7\% dan WBP wanita 4\%, depresi mayor pada Warga Binaan Pemasyarakatan pria sebanyak $10 \%$ dan wanita sebesar $12 \%$ (WHO conference on women's health in prison, 2008).

Fazel (2002) juga melakukan studi yang sama dengan melibatkan sejumlah tahanan berjumlah 10.529 orang, tahanan laki-laki yang berjumlah 7.631 diindikasikan terdiagnosis depresi berat. Studi lain yang dilakukan di Lembaga Pemasyarakatan wanita di Kota Semarang mengkonfirmasi sebanyak 14 Tahanana Wanita terdiagnosis mempunyai rasa takut yang berlebih, merasa sedih, memiliki ketegangan yang meningkat, merasa kebingungan, dilanda kekecewaan yang mendalam, merasa malu, sering menangis tanpa sebab, suka melamun, suka menyendiri, mengali susah tidur, merasa putus asa, mengalami sakit kepala dan perut tanpa sebab, dan mengaku badan seringkali mudah sakit (Noorsifa, 2013). Peneliti lain juga melakukan studi yang serupa di Lembaga Pemasayarakatan Klas I yang melibatkan 24 Warga Binaan Pemasyarakatan didapatkan hanya ada 4 orang $(16,7 \%)$ tidak mengalami permasalahan yang bersifat psikologis (normal), depresi ringan 12,5 \% (3 orang), depresi sedang 20,8\% (5orang), sedangkan WBP yang mengalami depresi berat sebanyak 50\% (12 orang). Hal tersebut mengindikasikan 
bahwa mayoritas WBP yang ada di Lembaga tersebut mengalami permasalahan psikologis yang membutuhkan intervensi lebih lanjut.

Simptom (gejala utama) yang dialami oleh seseorang yang mengalami depresi diantaranya yaitu konsentrasi dan perhatian berkurang; harga diri dan kepercayaan diri berkurang; gagasan tentang rasa bersalah dan tidak berguna; pandangan masa depan yang suram dan pesimis; gagasan atau perbuatan membahayakan diri atau bunuh diri; mengalami gangguan tidur; nafsu makan berkurang (Maslim, 2013)

Depresi dapat didefinisikan sebagai gangguan yang tidak bersifat afek saja, tetapi dapat pula muncul dalam bentuk-bentuk yang lain. Bentuk-bentuk tersebut adalah; a. Memiliki perubahan suasana hati yang spesifik seperti kesedihan, merasa sendiri dan apatis; b. Selalu menyalahkan diri sendiri serta mencela diri sendiri secara berlebihan (Konsep diri negatif); c. Keinginan-keinginan regresif dan menghukum diri sendiri, keinginan menghindar bersembunyi atau keinginan untuk mati; $d$. perubahanperubahan vegetatif seperti anoreksia, insomnia, dan kehilangan nafsu makan; e. perubahan dalam tingkat aktivitas seperti retardasi atau agitasi (Beck, 1985)

Menurut diagnostic and statistical manual of mental disorders edisi ke-5 (DSM V, 2013) seseorang dikatakan depresi harus memiliki 5 atau lebih gejala selama 2 minggu atau lebih, salah satu gejala harus termasuk penurunan mood atau hilangnya minat atau kesenangan dalam sebagian atau semua aktivitas dan harus ada sepanjang hari atau hampir setiap hari. Gejala lainnya meliputi perubahan nafsu makan (meningkat atau menurun), berat badan (memperoleh atau kehilangan 5\% dalam 1 bulan) atau tidur (insomnia/hypersomnia), kegelisahan atau kelambanan, kelelahan atau hilangnya energi, perasaan tidak berharga atau rasa salah berlebihan, kesulitan berpikir dan berkonsentrasi, lambat dalam membuat keputusan, adanya pikiran berulang untuk bunuh diri atau kematian dengan atau tanpa rencana bunuh diri.

Situasi diatas memperlihatkan bahwa Warga Binaan Pemasayrakatan merupakan kelompok berisiko mengalami masalah psikologis khususnya depresi. Apabila kondisi tersebut tidak mendapatkan intervensi maka akan mempengaruhi kondisi mental dan semakin menambah tugas dari lembaga pemasyarakatan untuk menanganinya. Penelitian ini kemudian bertujuan untuk mendeskripsikan tingkat depresi yang dialami oleh WBP serta untuk mengetahui mengetahui efek pemenjaraan terhadap kondisi depresi pada Warga Binaan Pemasyarakatan X.

\section{Metode}

Partisipan dalam penelitian ini adalah Warga Binaan Pemasyarakatan (WBP) Lapas X yang berlokasi di Kota Semarang, Jawa Tengah. Jumlah Partisipan dalam penelitian ini 6 orang WBP kasus Pembunuhan umum. Karakteristik partisipan ini ialah WBP yang pernah membunuh dan mempunyai status Narapidana (berkekuatan hukum tetap/inkracht). Metode pengambilan data penelitian ini Wawancara, observasi serta pemberian skala BDI-II.

\section{Pengukuran}

Data kuantitatif yang berkaitan dengan kondisi yang dialami oleh Warga Binaan Pemasyarakatan khususnya depresi didapatkan dengan cara memberikan isian skala Beck Depression Inventory II (BDI - II). Beck Depression Inventory II (BDI-II) ini untuk mengukur tingkat depresi yang dialami oleh individu. 
Instrumen ini disusun untuk subjek yang berusia 13 tahun keatas dan terdiri dari pertanyaan yang berhubungan dengan gejala depresi seperti keputusasaan dan marah, kognisi, seperti perasaan bersalah atau dihukum, serta gejala fisik seperti kelelahan, penurunan berat badan dan kurangnya minat pada aktivitas seks (Beck, 1985). Instrumen BDI terdiri dari 21 item pernyataan yang akan mengidentifikasi tingkat keparahan depresi. Koefisien reliabitas $\alpha$ instrumen yang digunakan dalam penelitian ini adalah 0.84. Total sor berkisar antara 0 sampai 63 . Semakin tinggi skor yang diperoleh menunjukkan semakin tinggi tingkat depresi seseorang.

\section{Analisis Data}

Hasil dari penelitian ini dianalisa menggunakan analisa univariat dan dilaporakan dalam bentuk distribusi frekuensi dengan cara menggambarkan karakteristik demografi responden dan tingkat depresi WBP Lapas X.

Hasil

Hasil penelitian dapat dilihat pada Tabel 1 di bawah ini.

Tabel 1. Data demografi partisipan

\begin{tabular}{|c|c|c|c|c|c|c|c|}
\hline Nama & $\begin{array}{c}\text { Jenis } \\
\text { Kelamin }\end{array}$ & Vonis & $\begin{array}{c}\text { Usia saat } \\
\text { kejadian } \\
\text { perkara }\end{array}$ & $\begin{array}{c}\text { Usia } \\
\text { sekarang }\end{array}$ & Pendidikan & Pekerjaan & $\begin{array}{c}\text { Status } \\
\text { pernikahan }\end{array}$ \\
\hline TO & Laki - laki & 9 tahun & 20 tahun & 24 tahun & SMK & Pengangguran & $\begin{array}{c}\text { belum } \\
\text { menikah }\end{array}$ \\
\hline $\mathrm{FE}$ & Laki-laki & $\begin{array}{l}\text { Seumur } \\
\text { hidup }\end{array}$ & 23 tahun & 28 tahun & SMA & Wiraswasta & Menikah \\
\hline FA & Laki-laki & 5 tahun & 17 tahun & 18 tahun & SMA & Pelajar & $\begin{array}{c}\text { belum } \\
\text { menikah }\end{array}$ \\
\hline AN & Laki-laki & 15 tahun & 20 tahun & 23 tahun & SMP & Bengkel & $\begin{array}{c}\text { belum } \\
\text { menikah }\end{array}$ \\
\hline$B L$ & Laki-laki & 20 tahun & 22 tahun & 25 tahun & SMK & Pengangguran & Menikah \\
\hline SU & Laki-laki & 15 tahun & 23 tahun & 25 tahun & SMP & Pengangguran & $\begin{array}{l}\text { belum } \\
\text { Menikah }\end{array}$ \\
\hline
\end{tabular}

Data demografi pada tabel 1 menunjukkan bahwa bahwa rata-rata partisipan tergolong dalam masa dewasa awal (83.3 \%) dan semua berjenis kelamin laki-laki. Sebanyak 4 orang $(66.7 \%)$ WBP yang melakukan pembunuhan berijazah SMA/SMA. Sebanyak 4 orang (66.7\%) partisipan bestatus menikah ketika melakukan pembunuhan. Sebanyak 3 WBP yang melakukan pemmbunuhan berstatus pengangguran. Dari keseluruhan WBP yang menjadi partisipan mendapatkan vonis/masa hukuman diatas 
10 tahun (83.3\%) dan hanya satu partisipan yang mendapatkan hukuman di bawah 10 tahun karena berstatus sebagai anak-anak.

Tabel 2. Kronologis dan status korban

\begin{tabular}{|c|c|c|c|c|c|c|c|c|}
\hline Nama & $\begin{array}{c}\text { Motif } \\
\text { membunuh }\end{array}$ & $\begin{array}{c}\text { Usia } \\
\text { Korban }\end{array}$ & $\begin{array}{c}\text { JK } \\
\text { Korban }\end{array}$ & $\begin{array}{c}\text { Pekerjaan } \\
\text { korban }\end{array}$ & $\begin{array}{c}\text { Hubungan } \\
\text { dengan } \\
\text { korban }\end{array}$ & $\begin{array}{l}\text { Alat yang } \\
\text { digunakan }\end{array}$ & Lokasi & $\begin{array}{c}\text { Status } \\
\text { drug }\end{array}$ \\
\hline TO & dendam & 30 tahun & Laki-laki & Satpam & Tetangga & Parang & $\begin{array}{l}\text { Rumah } \\
\text { korban }\end{array}$ & Mabuk \\
\hline $\mathrm{FE}$ & dendam & $\begin{array}{c}28 \text { dan } \\
29 \text { tahun }\end{array}$ & $\begin{array}{l}\text { Laki-laki } \\
\qquad(2 \\
\text { orang) }\end{array}$ & Preman & Tidak kenal & $\begin{array}{l}\text { Pisau } \\
\text { dapur }\end{array}$ & $\begin{array}{c}\text { Kompleks } \\
\text { korban }\end{array}$ & Sadar \\
\hline FA & dendam & 28 tahun & Laki-laki & Karyawan & Teman & $\begin{array}{l}\text { Pukul/Tan } \\
\text { gan } \\
\text { kosong }\end{array}$ & Stadion & Sadar \\
\hline AN & $\begin{array}{l}\text { Melumpuhk } \\
\text { an }\end{array}$ & 40 tahun & Laki-laki & Satpam & Orang lain & $\begin{array}{l}\text { Balok } \\
\text { Kayu }\end{array}$ & $\begin{array}{c}\text { Tempat } \\
\text { kerja } \\
\text { korban }\end{array}$ & Sadar \\
\hline$B L$ & dendam & 75 tahun & Laki-laki & Bos & Mantan Bos & $\begin{array}{l}\text { Plastik } \\
\text { dan } \\
\text { tangan } \\
\text { kosong }\end{array}$ & $\begin{array}{l}\text { Rumah } \\
\text { korban }\end{array}$ & Sadar \\
\hline SU & dendam & 26 tahun & Laki-laki & $\begin{array}{l}\text { Penjaga } \\
\text { warnet }\end{array}$ & Teman & Celurit & $\begin{array}{c}\text { Tempat } \\
\text { kerja } \\
\text { korban }\end{array}$ & Sadar \\
\hline
\end{tabular}

Pada tabel 2 diatas dapat dijelaskan, terkait dengan status kondisi kesadaran, sebanyak 5 orang WBP ketika melakukan pembunuhan dalam keadaan sadar (tidak dipengaruhi oleh obat-obatan/minuman keras). Pembunuhan yang dilakukan oleh WBP rata-rata bermotifkan dendam (83.3\%). Pada kasus pembunuhan yang dilakukan oleh WBP, semua korban berjenis kelamin Laki-laki dan tergolong dalam usia dewasa (83.3\%) serta dikenal oleh WBP (83.3\%). Alat yang digunakan untuk membunuh korban beragam mulai dari parang, pisau, balok dan celurit. Hanya 1 WBP (16.7\%) yang menggunakan tangan kosong untuk membunuh korban karena WBP tersebut seorang atlit pencak silat. Aktivitas pembunuhan yang dilakukan oleh WBP dilakukan diluar rumah korban (50\%). 
Tabel 3. Kondisi Psikologis WBP

\begin{tabular}{ccc}
\hline Partisipan & Skor BDI & Kategori \\
\hline TO & 28 & Depresi Berat \\
FE & 32 & Depresi Berat \\
FA & 28 & Depresi Berat \\
AN & 26 & Depresi Berat \\
BL & 31 & Depresi Berat \\
SU & 32 & Depresi Berat \\
\hline
\end{tabular}

Hasil yang diperlihatkan pada table 3, ketika diambil data yang berkaitan dengan kondisi psikologis WBP dengan menggunakan skala BDI-II menunjukkan semua WBP yang menjadi partisipan dalam penelitian ini mempunyai kategori Depresi Berat (100\%).

\section{Analisis Kualitatif Partisipan TO}

Partisipan TO seorang laki-laki berusia 24 tahun. TO mempunyai tinggi badan sedang $+/-160 \mathrm{~cm}$, badan agak kurus, mata sedikit membelalak, muka oval, rabut pendek disisir arah kiri, kulit berwarna cokelat dan di bagian kaki sebelah kiri ada gambar tato. la merupakan anak pertama dari dua bersaudara (adik perempuan), yang lahir dari pasangan AB dan AS. Orangtua TO tinggal di daerah Semarang, Ayahnya bekerja di salah satu Sekolah Menengah Atas di Kota A sedangkan ibunya sebagai ibu rumah tangga.

Berdasarkan wawancara, pada tanggal 22 Januari 2013 di suatu daerah di Kota Semarang, ia melakukan tindak pidana pembunuhan tidak berencana/pengeroyokan yang mengakibatkan kematian, hal tersebut melanggar (Pasal 170 dan 338). Oleh sebab itu, partisipan TO divonis hukuman 9 tahun penjara dan sudah menjalani masa hukuman sekitar hampir 4 tahun mulai Maret 2013.

Partisipan sangat menyesal telah melakukan tindak pidana pembunuhan karena pada saat kejadian itu. TO dalam keadaan tidak sadar/ terpengaruh minuman beralkohol. la juga merasa bersalah dan menyesal hingga saat ini karena telah membunuh kakak temannya. Hal lain yang dirasakan ialah ia selalu khawatir adik korban menaruh dendam kepada keluarganya dan merasa takut jika sewaktu-waktu keluarganya akan di lukai oleh adik korban. TO juga mencemaskan masa depannya yang tidak menentu karena masa hukumannya yang relatif lama. Situasi lingkungan Blok Lapas juga terkadang membuat TO merasa tidak nyaman jengkel. la juga merasa tidak dihargai dan dipandang sebelah mata karena ia dicap sebagai anak nakal dan dikucilkan dari lingkungan Blok D.

\section{Analisis Kualitatif Partisipan FE}

Partisipan FE seorang laki-laki berusia 28 tahun. FE mempunyai tinggi badan $+/-165 \mathrm{~cm}$, badan kekar berisi, lengan bagian bisep dan trisep terlihat menonjol kekar, rambut pendek, muka oval dan memakai kaca mata frame hitam tebal dan kulit berwarna cokelat. FE merupakan anak pertama dari 2 bersaudara pasangan suami istri DA dan SE. Orangtua FE tinggal bersama istrinya dan anaknya di Kota B Jawa Tengah. 
Kejadian tindak pidana pasal 340 (pembunuhan berencana) yang dilakukan FE terjadi pada bulan September 2011. Awalnya FE mendapatkan pengaduan dari adiknya yang masih SMP. Adik FE mengatakan/menceritakan kalau baru saja dipukuli oleh seseorang yang tidak dikenal.

Hasil asesmen yang dilakukan terhadap FE didapatkan, ia merasa tidak nyaman dengan lingkungan Lapas terutama dengan kondisi Blok dengan WBP yang tidak dapat saling menghargai dan menghormati oranglain. Setiap hari FE melihat WBP bertengkar atau saling membicarakan di belakang sehingga hal tersebut membuat FE kepikiran sepanjang hari. FE juga mengkhawatirkan kondisi rumah tangganya yang hampir memasuki tahun ketujuh, padahal hukuman yang akan dijalaninya seumur hidup. FE selalu mencemaskan nasib anak laki-laki semata wayangnya yang saat ini berusia 5 tahun. FE adalah orang yang sayang keluarga, tidak bisa jauh dari keluarga, namun kondisi yang memaksa ia untuk menerima kenyataan hidup di dalam Lapas membuat FE mengalami tekanan psikologis (merasa sedih, pesimis, ketidakpuasan terhadap vonis hukuman serta perasaan bersalah selalu menjadi pikirannya sehingga ia merasa pantas untuk mendapatkan hukuman).

\section{Analisis Kualitatif Partisipan FA}

Partisipan FA seorang laki-laki berusia 18 tahun. FA mempunyai Tinggi badan $+/-160 \mathrm{~cm}$, badan kecil agak kurus, kulit cokelat, raut muka seperti chinese, pada muka terdapat banyak noda hitam bekas jerawat, rambut cepak pendek samping kiri dan kanan ditipiskan. FA merupakan anak pertama dari dua bersaudara yang lahir dari pasangan JU dan JH. Orangtua FA tinggal di kota $\mathrm{C}$ dan berprofesi sebagai wiraswasta di bagian perdagangan.

Kejadian tindak pidana yang dilakukan oleh FA ialah melanggar pasal 170 ayat 1 dan 2 (Perkelahian menyebabkan kematian/pembunuhan). Tindak pidana tersebut dilakukan oleh FA pada tanggal 1 Juli 2015. Pada saat terjadi tindak pembunuhan FA masih berumur 17 tahun dan dikategorikan sebagai WBP anakanak. Awal terjadinya pembunuhan ialah adanya kesalahpahaman.

Kondisi psikologis FA menunjukkan bahwa ia merasa tidak nyaman lagi berada di blok anak-anak karena usianya kini sudah 18 tahun yang sudah dapat dikategorikan sebagai WBP dewasa. la sering mengajukan kepada BIMPAS untuk segera pindah ke Blok dewasa namun belum ada tanggapan dan menunggu surat perintah pemindahan dari Kalapas. Di blok anak-anak juga kurang bebas karena tidak dapat melakukan aktivitas yang disukai karena jumlahnya sangat terbatas seperti main futsal dan olahraga yang lainnya. Hal tersebut membuat FA selalu jengkel karena tidak mendapatkan tanggapan dari pihak Lapas untuk segera pindah.

Permasalahan lain yang dialami FA ialah ia merasa sangat menyesal sudah melakukan tindakan pembunuhan terhadap teman mainnya sendiri, terlebih lagi keluarga korban sudah menganggap dirinya sebagai anaknya. Namun akibat tidak dapat mengontrol emosi ia melakukan tindakan pembunuhan yang tidak ia sengaja, dan awalnya hanya ingin memberikan pelajaran kepada korban. Penyesalan tersebut menambah rasa khawatir terhadap situasi mengenai hubungan keluarga korban dan keluarganya yang sudah terjalin sejak ayah dan ibu FA masih usia anak-anak karena mereka berteman sejak dari anak-anak. FA merasa sudah merusak hubungan kekeluargaan orangtuanya dengan orangtua korban. Setelah FA keluar dari Lapas Klas I Semarang maka ia akan menyandang status sebagai mantan Napi, hal tersebut 
membuat FA merasa takut untuk kembali ke masyarakat. FA juga mengaku sangat kangen dengan orangtua karena sudah satu bulan tidak dijenguk oleh orangtua.

\section{Analisis Kualitatif Partisipan AN}

Partisipan AN seorang lelaki berusia 23 tahun. AN mempunyai tinggi badan (+- $165 \mathrm{~cm}$ ), warna kulit cokelat, muka oval, mata agak lebar, rambut cepak pendek bagian kiri dan kanan ditipiskan dan bagian kanan diberi "line" / garis. Terdapat tato bintang berjumlah 3 buah dibagian leher kiri atas, dibawah telinga juga terdapat tato bintang berjejer ke bawah semakin mengecil. Lengan bagian kiri dalam terdapat tato bertuliskan kata "i love you". AN merupakan anak kedua dari 2 bersaudara dari pasangan orangtua BS dan AD. Orangtua dan saudara AN tinggal di kota D Jawa Tengah.

Tidak pidana perampokan dan pembunuhan 365 dan 338 yang dilakukan oleh AN terjadi pada bulan Januari 2014. Sebelumnya AN telah melakukan pekerjaan (mencuri) sebanyak 7 kali namun ia tidak pernah tertangkap.

Kondisi psikologis AN menunjukkan, ia sangat menyesal dan merasa malu terhadap ibu kos dan tetangganya karena telah melakukan usaha perampokan dan pembunuhan. AN juga merasa pesimis dengan masa depan ketika nanti kembali ke tengah-tengah lingkungan masyarakat. Masyarakat jadi mengetahui kalau selama ini AN adalah perampok dan pembunuh. AN juga merasa kondisi Lapas tidak kondusif karena terdapat beberapa teman yang sering berkonflik dengannya. Selama ini AN merasa aman tidak ada yang berani menyentuhnya karena di dalam Lapas/blok ada orang yang dianggap sebagai orangtuanya sendiri (bapak angkat). AN juga merasa bahwa ia menjadi korban penyalahgunaan narkoba. Hal tersebut membuat ia serba salah, jika ia berhenti mengkonsumsi narkoba maka bisa saja ia semakin menderita secara fisik dan psikologis karena tidak melalui rehabilitasi, namun jika minta direhabilitasi oleh pihak Lapas, kemungkinan kesempatan untuk dikabul kan sangat tipis. AN mengalami kesedihan, perasaan pemistis, adanya perasaan ketidakpuasan dan adanya perasaan bersalah/sedang dihukum.

\section{Analisis Kualitatif Partisipan BL}

Partisipan BL seorang laki-laki berusia 25 tahun. BL mempunyai tinggi badan (+- $165 \mathrm{~cm})$, badan gemuk, perut buncit, muka bulat dan mata agak lebar. Ada noda hitam di bagian wajah bekas jerawat, rambut cepak pendek sasak tipis. Kedua orangtua BL sudah meninggal sejak 7 tahun yang lalu. BL merupakan anak pertama dari tiga bersaudara. Semua saudaranya tinggal di Pemalang, hanya dirinya yang merantau ke Semarang sejak 4 tahun yang lalu.

Kejadian tindak pidana pasal 365 (perampokan dan pembunuhan berencana) yang dilakukan BL terjadi pada bulan Januari 2014. Tiga bulan sebelum terjadinya kasus pembunuhan, partisipan bekerja di salah satu showroom mobil yang dimiliki oleh pasangan chinese. Selama bekerja tiga bulan, BL merasa diperlakukan semena-mena. Menurut penuturan BL, ia sering mendapatkan kata-kata umpatan dari majikannya ketika melakukan kesalahan kecil.

Kondisi psikologis BL menunjukkan, bahwa selama ini ia kepikiran dengan hukum karma, siapa yang berbuat maka suatu saat ia akan menerima balasannya, balasan itu entah dimana tempatnya, bisa di dalam Lapas atau ketika nanti bebas tiba-tiba meninggal. BL juga mengkhawatirkan tentang masa depannya yang 
tidak pasti, ia akan mengalami tua di dalam Lapas karena ia mendapatkan hukuman 20 tahun penjara karena ia adalah otak perampokan dan pembunuhan. BL juga merasa sakit hati karena telah di cerai istrinya karena ia masuk penjara, sejak terjadi perceraian tahun 2015, ia sering memikirkan betapa sakit hati ketika istrinya yangia sayangi tiba-tiba datang dan minta cerai. Padahal istrinya adalah satu-satunya harapan untuk berkeluh kesah disaat keluarganya sudah tidak peduli dengan BL. Di Blok D BL juga mempunyai masalah dengan WBP lainnya, dagangan bubur ayamnya yang menjadi sumber pendapatannya selalu dihutang oleh WBP lain yang menyebabkan ia tidak dapat mengembalikan modal dan membeli bahan untuk membuat bubur ayam.

Pada saat dilakukan asesmen, didapatkan hasil bahwa mood yang dimiliki BL sangat rendah artinya ia memiliki kesedihan, merasa pesimistis terhadap pelatihan, ada ketidakpuasan dalam kehidupan serta berkaitan dengan kurangnya penerimaan vonis hukuman yang dijatuhkan terhadap BL.

\section{Analisis Kualitatif Partisipan SU}

Partisipan SU seorang laki-laki berusia 25 tahun. SU mempunyai tinggi badan $(+-175 \mathrm{~cm})$, badan tinggi kurus, mata agak sipit, mulut agak lebar, hidung besar, kumis tipis, muka lonjong lebar, rambut agak jabrik pendek, bentuk kaki seperti huruf O (terlihat jika SU jalan), warna kulit cokelat.

Kejadian tindak pidana pasal 340 (pembunuhan berencana) yang dilakukan BL terjadi pada bulan November 2014. Kejadian berawal dari SU yang diajak oleh temannya yang akan menyelesaikan masalah. SU tidak mengetahui urusan apa yang sebenarnya terjadi. SU menerima ajakan dari dari temannya karena sudah dianggap sebagai keluarga sendiri. Sesampai di lokasi, SU hanya mendengarkan temannya menyelesaikan masalahnya. Menurut SU, korban memang seringkali melontarkan kata-kata makian dan hinaan yang membuat SU merasa sakit hati. SU juga merasa tersinggung ketika korban menghina dirinya seperti itu.

Kondisi Psikologis SU menunjukkan, SU sangat menyesal telah melakukan tindak pidana pembunuhan, BL juga merasakan jika semakin jauh dengan keluarga karena telah mengecewakan keluarga. Selama ini SU merasa sudah tidak diperhatikan oleh keluarga. Ketika SU mendekam di Lapas pun keluarga jarang ada yang mau membesuk hal tersebut membuat SU rindu dengan keluarga. SU juga terkadang mendapatkan ledekan dari teman-teman satu bloknya karena ia dianggap orang yang "kurang", keterbatasan kognitif membuat SU sulit mengikuti alur pembicaraan orang lain. BL juga sering mendapatkan sasaran ledekan dari teman-temannya, BL diledek seperti jerapah karena orangnya tinggi tapi kakinya bengkok seperti huruf $\mathrm{O}$. Ledekan-ledekan seperti itu awalnya dianggap biasa oleh SU tapi lama-kelamaan, hal tersebut membuat SU kurang percaya diri ketika bergaul dengan lingkungan blok.

Pada saat dilakukan asesmen, SU mengalami permasalahan yang kompleks yang berkaitan dengan dirinya sendiri. SU mengalami kesedihan, adanya rasa pesimis, kurang menerima vonis hukuman 15 tahun, SU sering kali mendapatkan masalah dalam hidupnya. BL sulit untuk mengatasi permasalahan yang menimpanya, kurang mampu untuk komunikasi dengan orang lain. 


\section{Pembahasan}

Hasil penelitian menunjukkan bahwa kondisi depresi partisipan penelitian secara keseluruhan mengalami Depresi Berat. Hal tersebut dapat disebabkan oleh faktor yang ada dalam diri WBP (internal Faktor) dan faktor yang ada diluar diri WBP (Eksternal factor). Faktor yang berkaitan dengan internal yaitu WBP merasa khawatir dan cemas atas segala hal yang akan menimpa setelah bebas nanti, merasa pesimis akan masa depan, takut kembali ke lingkungan masyarakat, adanya ketidakpuasan terhadap vonis yang telah dijatuhkan, penyesalan yang berlebih, ada perasaan malu dengan label Narapidana, merasa sedih. Sedangkan faktor eksternal yang mempengaruhi kondisi mental WBP yaitu kondisi sosial blok yang tidak bersahabat (tidak saling menghargai, memandang orang sebelah mata), adanya konflik di dalam blok, istri minta cerai, keluarga tidak peduli.

Sosrokartono (dalam Syuropati, 2011) menyatakan bahwa berbagai macam emosi negatif hanya akan menyebabkan ketegangan dan kegelisahan dalam hidup. Dengan memiliki persepsi dan penilaian yang positif terhadap ujian dan masalah hidup seorang partisipan lebih mampu untuk mengelola perasaan, sehingga perasaan-perasaan yang muncul akan juga akan menjadi lebih positif.

Lamanya masa tahanan juga berdampak terhadap kondisi psikologis WBP, karena mereka harus berhadapan dengan kondisi yang tidak sesuai dengan yang diharapkan atau kondisi yang tidak menyenangkan, sehingga mengalami stress, cemas, kesedihan serta mudah tersinggung (Tololiu, makalalag, 2015). Allender dan Spradley (2005) juga menambahkan bahwa perasaan sedih cemas dan terancam membuat narapidana sangat rentan terhadap permasalahan psikologis seperti depresi. Jika kondisi seperti ini tidak segera diselesaikan maka bukan tidak mungkin WBP akan melakukan tindakan yang diluar perkiraan sebelumnya misalnya bunuh diri ataupun berbuat agresif.

\section{Saran dan Kesimpulan}

Warga Binaan Pemasyarakatan dalam penelitian ini memiliki kondisi depresi berat. Hal tersebut dapat disebabkan karena lamanya hukuman yang diterima oleh WBP dalam menjalani hukuman. Narapidana dengan masa hukuman lebih dari 5 tahun mempunyai kecenderungan mengalami depresi lebih tinggi dibanding dengan Narapidana yang mendapatkan hukuman dibawah 5 tahun (Kaloeti, dkk. 2017).

Melihat kondisi yang telah dibahas, maka dapat diberikan saran pengembangan untuk Lapas terkait dengan permasalahan yang sedang dihadapi oleh WBP. Lapas dapat melakukan pelatihan secara rutin dengan melibatkan kerjasama dengan profesional di bidangnya, misalnya trainer psikologi atau semacamnya. Training yang diberikan dapat beragam misalnya terapi kebersyukuran, karena dengan meningkatkan rasa sykur rasa bersukur dapat meningkatkan kebahagiaan, serta mengurangi depresi (Wood, Frohdan Geraghty, 2010) dan memiliki sikap positif (Raggio dan Folse, 2009). Wood, Maltby, Gillett, Linley,\& Joseph (2008) juga menyatakan bahwa rasa syukur yang tinggi akan membuat seseorang melihat situasi adalah sesuatu yang menguntungkan. Pikiran yang benar, perasaan yang benar, perkataaan yang benar dan perbuatan yang benar akan senantiasa menghindarkan diri kita dari hal-hal yang bersifat negatif (Sosrokartono dalam Syuropati, 2011). Pelatihan lain yang dapat direkomendasikan ialah Pelatihan 
Zamroni

narima ing pandum dapat menurunkan depresi (zamroni, 2016), Widiasari (2015) juga membuat penelitian emphatic love therapy untuk menurunkan depresi.

\section{Daftar Pustaka}

Ahmad, A. \& Mazlan, N. H. (2014). Stress and depression: A comparison study between men and women inmates in Peninsular Malaysia. International Journal of Humanities and Social Sciences, 4(2), 153-160.

Allender \& Spradley. (2005). Community Health Nursing: Concept and Practice. Philadelhia: Lippincott.

American Psychiatric Association.(2013). Diagnostic and Statistical Manual of Mental Disorder (fifth edition). Washington, DC : Author.

Beck, A.T. (1985). Causes and Treatment. Philadelphia: University of Pennsylvania Press.

Fazel, S., Danesh, J. (2002). Serious mental disorder in 23.000 prisoners : a systematic review of 62 Surveys. The Lancet.vol 359. February 16, 2002.

Gussack, D. (2009). The art in psychoteraphy comparing the effectiveness of art therapy on depression and locus of control of male and female inmate. The art in psychoterapy, 36, 202-207.

Kaloeti, Rahmandani, Salma, La Kahija, Sakti, (2017). Gambaran Depresi Warga Binaan Pemasyarakatan X. Jurnal Psikologi. Volume 13. Nomor 2. Tahun 2017

Maslim, R. (2013). Buku Saku Diagnosis Gangguan Jiwa Rujukan Ringkas dari PPDGJ-III dan DSM-5. Jakarta : PT. Nuh Jaya.

Noorsifa, (2013). Korelasi Resiliensi dengan Depresi pada Narapidana Wanita di Lembaga Pemasyarakatan klas II A Banjarmasin.Tesis. (Tidak Diterbitkan). Yogyakarta: Program Pascasarjana Universitas Gadjah Mada.

Raggio, R.D., Folse, J.A.G. (2009). Gratitude Works: Its Impact And The Mediating Role Of Affective Commitment In Driving Positive Outcomes. Journal of the Academik Marketing Science, 37, 455469. doi 10.1007/s11747-009-0144-2.

Syuropati.A.M. (2011). Teori sastra kontemporerv \& 13 tokohnya (sebuah perkenalan). Yogyakarta : IN Azna Books. 
Tololiu, Makalalag, (2015). Hubungan Depresi dengan Lama Masa Tahanan Narapidana di Rumah Tahanan Negara Kelas IIA Malendeng Manado. Juperdo. Volume 4. Nomor 1. Tahun 2015

Tomar, S. (2013). The psychological effects of incarceration on inmates: Can we promote positive emotion inmates?. Delhi Psychiatry Journal, 16, 64-72.

WHO Conference on Womens's Health in Prison. (2008). Correcting Gender Inequities inPrison Heatlh. Consultative Document for Discussion at the WHO International. Conference on Prison HealthKyiv, Ukraine 13 November.Ukraine.

Widiasari, E. (2015). Emphatic Love Therapy untuk Menurunkan Depresi.Tesis. (Tidak Diterbitkan). Yogyakarta: Program Pascasarjana Universitas Gadjah Mada.

Wood, A.M., Froh, J.J., Geraghty, A.W.A. (2010). Gratitude And Well-Being: A Review And Theoretical Integration. Clinical Psychology Review,890-905.

Wood, A. M., Maltby, J., Gillett, R., Linley, P. A., \& Joseph, S. (2008). The Role of Gratitude In the Development of Social Support, Stress, and Depression: Two Longitudinal Studies. Journal of Research in Personality, 42, 854-871.

Zamroni, (2016). Pelatihan Kelompok Narima Ing Pandum (NIP) untuk Menurunkan Depresi pada Warga Binaan Pemasyarakatan Kasus Pembunuhan di Lembaga Pemasyarakatan Klas 1 Kota Semarang. Tesis. (Tidak Diterbitkan), Surakarta: Program Pascasarjana Universitas Muhammadiyah Surakarta. 